\title{
Pyogenic Infection of Liver Secondary to Infection in the Portal Drainage Area
}

\author{
C. G. McKENZIE,* F.R.C.S.
}

Brit. med. F., 1964, 2, 1558-1563

This condition is a result of bacterial infection reaching the portal tracts from an infective lesion in the portal drainage area and producing periportal inflammation which may proceed to suppuration. These cases provide a diagnostic and therapeutic problem which it is the object of this paper to discuss.

The types of lesion which may occur may be divided into two groups: (1) pylephlebitis, and (2) solitary pyogenic liver abscess. It was emphasized by Eliason (1926) that the terms "pylephlebitis" and "pyogenic liver abscess" should not be used synonymously. Pylephlebitis is a septic thrombophlebitis of the portal vein or its branches. This condition may resolve with or without treatment or it may proceed to suppuration and abscess formation. Solitary liver abscess may result from infection reaching the liver by numerous routes. This paper is concerned only with those cases in which the route of infection is by the portal vein and the responsible organism is one of the pyogenic bacteria. Abscesses due to actinomycosis and amoebae are excluded.

Pyogenic abscesses are probably secondary to pylephlebitis which has not been recognized and has resolved except for leaving an abscess in the liver.

The essential feature of pylephlebitis is the presence of infected thrombi in the portal vein or its branches. A case of pyogenic abscess of the liver may not show this lesion, and the question then remains whether the path of spread from the primary focus was by the portal venous system. The route by which the infection spread is especially open to question in those cases that have no demonstrable primary intra-abdominal infection. Rothenberg and Linder (1934) thought that infection from pharyngeal or cutaneous foci via the hepatic artery was a frequent cause, but were unable to prove this connexion.

From a consideration of the post-mortem appearance of these abscesses Beaver (1931) concluded that they resulted from the entry into the portal blood-stream of multiple infected emboli or discrete masses of bacteria. . Stokes (1960) reported a personal series of six cases and thought that the origin of infection in these cases was from the portal drainage area. He pointed out that the organisms causing these abscesses were of the type derived from the bowel.

The Table gives the clinical and laboratory features of eight cases, and reports of three of these are presented and discussed.

\section{Case 3}

A man aged 53 was admitted to the London Hospital on 15 September 1958 with a history that eight days prior to admission he collapsed while getting into his car and was briefly unconscious. When he recovered consciousness he felt very weak and vomited. During the following night he had a rigor and his temperature was recorded as being $105^{\circ} \mathrm{F}$. $\left(40.6^{\circ} \mathrm{C}\right.$.). The next day he was febrile and was noticed to be slightly jaundiced. He remained febrile and had multiple rigors but never experienced abdominal pain.

On examination he was seen to be an obese middle-aged man. His temperature was $99.5^{\circ}$ F. $\left(37.5^{\circ}\right.$ C.) and pulse 80. His skin was mildly jaundiced. The liver was just palpable below the right costal margin.

Investigations. - White-cell count 11,000/c.mm. (polymorphs $76 \%$ ). E.S.R. $50 \mathrm{~mm}$. in one hour. Liver-function tests showed: bilirubin $5 \mathrm{mg} . / 100 \mathrm{ml}$; alkaline phosphatase $15 \mathrm{~K}$.A. units; thymol turbidity 5.8 units; albumin $3.8 \mathrm{~g} . / 100 \mathrm{ml} . ;$ globulin 3.8 g. $/ 100 \mathrm{ml}$.

He remained ill with a severe remittent fever and repeated rigors, and a provisional diagnosis of occult abdominal infection was made. Treatment with penicillin 500,000 units b.d. was started two days after admission and the dose was increased to $1,000,000$ units fourhourly two days later, but even this dose was without effect. One week after admission treatment with chlortetracycline $250 \mathrm{mg}$. q.d.s. was started, and after two days his rigors ceased and his fever began to subside.

Liver-function tests (10 days after admission) showed: bilirubin $1.2 \mathrm{mg} . / 100 \mathrm{ml}$; alkaline phosphatase 44 K.A. units; thymol turbidity 4.1 units; zinc sulphate turbidity 6.8 units; albumin 3.8 g. $/ 100 \mathrm{ml}$. ; globulin $3.5 \mathrm{~g} . / 100 \mathrm{ml}$. Histological examination of a liver biopsy specimen taken nine days after admission showed non-specific inflammatory changes including polymorphs in the portal tracts, but no evidence of obstructive jaundice or virus hepatitis. These features may be related to a larger inflammatory process somewhere in the liver.

Sixteen days after admission a laparotomy was carried out. Macroscopically the liver was normal ; a duodenal ulcer was present, but no other detectable abnormality of the abdominal viscera was found. A partial gastrectomy was carried out because of the duodenal ulcer and a further biopsy specimen of liver was taken.

He made an uneventful recovery. Penicillin 500,000 units q.d.s. and streptomycin $0.5 \mathrm{~g}$. b.d. were given for five days, and all treatment was then discontinued. He was discharged on the twelfth post-operative day free from symptoms and fever.

Liver-function tests six days after operation showed an alkaline phosphatase of $21 \mathrm{~K}$.A. units but no other abnormality. Histological examination on the liver biopsy specimen taken at operation showed subacute purulent inflammation in the portal tracts with intralobular polymorphonuclear exudates and focal thrombophlebitis. The specimen provides evidence of sepsis in the portal drainage area.

\section{Case 9}

A man aged 45 was admitted to St. Margaret's Hospital, Epping, on 29 August 1962. Two days prior to admission he began to experience abdominal pain and vomited several times. Examination revealed slight tenderness in the right iliac fossa. A diagnosis of acute appendicitis was made.

Through a grid-iron incision an acutely inflamed retrocaecal appendix was removed. There was no free pus in the peritoneal cavity.

On the third post-operative day his temperature rose to $101^{\circ} \mathrm{F}$. $\left(38.3^{\circ}\right.$ C.). This fever persisted, becoming more severe over the next three days. The wound began to discharge a little pus which on culture grew Escherichia coli sensitive to chloramphenicol, streptomycin, and Colomycin (colistin) (see Fig. 1). Treatment with chloramphenicol $250 \mathrm{mg}$. q.d.s. was started, but his fever became more severe and he began to have rigors, in which his temperature rose to $105^{\circ} \mathrm{F}$. $\left(40.6^{\circ} \mathrm{C}\right.$.).

The condition was thought to be due to infection in the deeper part of the wound, and 10 days after appendicectomy his wound was explored. Some pus was present in the layers of the abdominal wall but no intraperitoneal abscess was found.

Streptomycin 0.5 g. b.d. and Colomycin $250 \mathrm{mg}$. q.d.s. were given for five days and his fever subsided. After treatment had

* Surgical Registrar, the London Hospital. Present address: Department of Sureery, Lakeside Hospital, Western Reserve University, Cleveland, Ohio. 
been discontinued he remained afebrile and symptom-free for five days, and was then discharged. He remained well for two weeks after discharge, then he vomited once after a heavy meal and began to experience increasingly severe epigastric pain. Five days later he was readmitted.

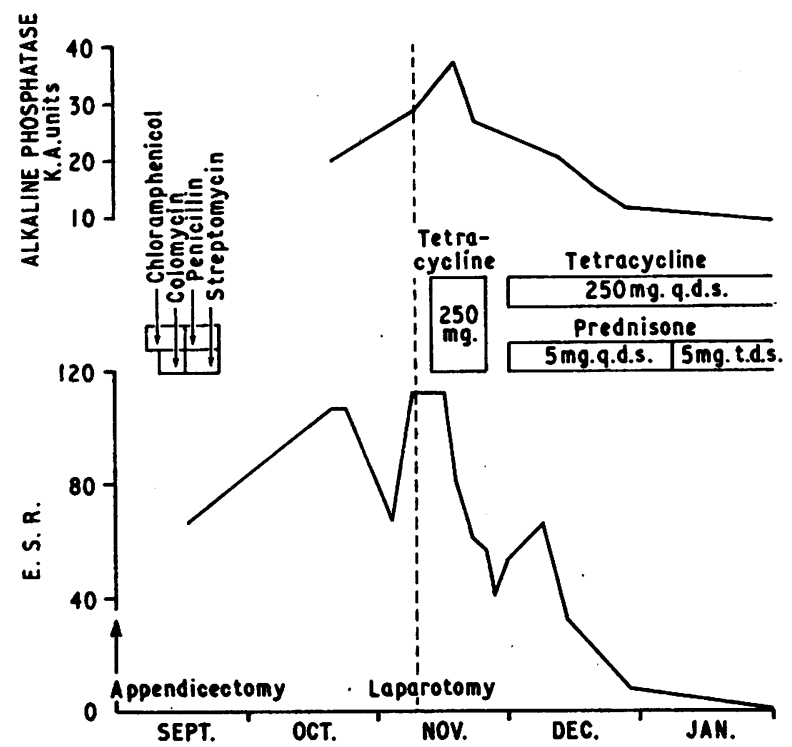

Fig. 1.-Case 9. Changes in E.S.R. and serum alkaline phosphatase that took place during treatment.

On examination he looked ill and had lost weight. His temperature was $98^{\circ} \mathrm{F}$. $\left(36.7^{\circ} \mathrm{C}\right.$.) and pulse 85 . There was slight tenderness in the epigastrium and right hypochondrium, but no masses were felt.

Investigations.-Haemoglobin $77 \%$; white-cell count 15,000/ c.mm. ; E.S.R. $115 \mathrm{~mm}$. in one hour ; blood culture sterile. Liverfunction tests showed: bilirubin $0.3 \mathrm{mg} . / 100 \mathrm{ml}$.; alkaline phosphatase 21 K.A. units ; thymol turbidity normal ; albumin $2.6 \mathrm{~g}$./ $100 \mathrm{ml}$.; globulin $4 \mathrm{~g} . / 100 \mathrm{ml}$. $X$-ray examination of the abdomen and screening of the diaphragm showed no evidence of subphrenic abscess.

His fever settled without antibiotic treatment and his general condition improved. He was discharged after 12 days, having been afebrile for four days. On discharge his white-cell count was $11,000 /$ c.mm. (polymorphs $49 \%$ ) and E.S.R. $74 \mathrm{~mm}$. in one hour.

Two days after discharge the epigastric pain recurred and gradually became worse. His appetite was poor and he had repeated shivering attacks. He was readmitted 12 days after he had been discharged.

On examination he looked ill and wasted. His tongue was furred. His temperature was $98^{\circ}$ F. $\left(36.7^{\circ} \mathrm{C}\right.$.) and pulse 85 . He had a tender rounded swelling, extending three fingerbreadths below the right costal margin.

Investigations.-Haemoglobin $68 \%$; white-cell count 17,900/ c.mm. (polymorphs 90); E.S.R. $108 \mathrm{~mm}$. in one hour. Liverfunction tests showed: bilirubin $0.4 \mathrm{mg} . / 100 \mathrm{ml}$.; alkaline phosphatase 27 K.A. units; thymol turbidity normal ; zinc sulphate turbidity normal ; albumin $2.7 \mathrm{~g} . / 100 \mathrm{ml}$. ; globulin $3.8 \mathrm{~g} . / 100 \mathrm{ml}$. Screening of the diaphragm showed impaired movement on the right side.

His temperature rose to 102 or $103^{\circ} \mathrm{F}$. $\left(38.9\right.$ or $39.4^{\circ} \mathrm{C}$.) on the two days subsequent to admission, and a provisional diagnosis of a right subphrenic abscess was made.

At operation the abdomen was explored through a right subcostal incision. No subphrenic abscess was found. The liver was enlarged, but needle aspiration failed to locate an intrahepatic abscess. A biopsy specimen of the liver was taken. Histological report on the biopsy specimen stated: The portal tracts are widened and infiltrated with plasma cells, lymphocytes, and a few leucocytes. Thrombus is present in the lumen of a branch of the vein, and though this thrombus appears bland it makes a diagnosis of pylephlebitis likely.

He was treated with tetracycline $250 \mathrm{mg}$. q.d.s. for 10 days, and transfused with 2 pints $(1,140 \mathrm{ml}$.) of blood to counteract the anaemia. The fever subsided and his general condition improved.
Investigations when antibiotic treatment was discontinued showed: haemoglobin $81 \%$; E.S.R. $54 \mathrm{~mm}$. in one hour; alkaline phosphatase $23 \mathrm{~K}$.A. units. He was discharged 10 days after operation.

One week after discharge he was again febrile, and had had several rigors. He looked ill, his haemoglobin had gone down to $70 \%$ and his E.S.R. was up to $65 \mathrm{~mm}$. in one hour. Readmission was advised, but this was refused. He remained at home and was treated with tetracycline $250 \mathrm{mg}$. q.d.s. and prednisone $5 \mathrm{~m} . \mathrm{g}$. t.d.s. His condition improved and three weeks later he was afebrile, symptom-free, and looking well.

Investigations showed: haemoglobin $86 \%$; white-cell count $11,000 /$ c.mm. ; E.S.R. $16 \mathrm{~mm}$. in one hour ; alkaline phosphatase 15 K.A. units ; albumin 3.7 g. $/ 100 \mathrm{ml}$. ; globulin $3.7 \mathrm{~g} . / 100 \mathrm{ml}$. Other liver function tests were normal.

Antibiotic and steroid therapy was continued for a further seven weeks and then discontinued, the dose of prednisone being gradually reduced.

Three weeks after discontinuing treatment investigations showed: haemoglobin $107 \%$; white-cell count $8,700 /$ c.mm ; E.S.R. $3 \mathrm{~mm}$. in one hour. Liver-function tests were normal.

\section{Case 7}

A man aged 41 was admitted to the London Hospital from the London Chest Hospital on 25 April 1963. One and a half years previously he had been admitted to the London Hospital with a nine-months history of lower abdominal pain, urgency of defaecation, and the passage of loose stools containing mucus. Rectal examination had revealed some induration outside the rectal wall above the prostate. A diagnosis of diverticulitis was made, being confirmed by barium enema, and he was discharged and followed as an outpatient. He remained well until, three weeks prior to admission, he began to experience right-sided chest pain and a productive cough.

On examination at the London Chest Hospital he was a pale, sweating, ill-looking man, temperature $101^{\circ} \mathrm{F} .\left(38.3^{\circ} \mathrm{C}\right.$.). He was not clinically jaundiced. There was dullness to percussion at the right base, with diminished breath sounds over the dull area. Liver and spleen were just palpable below the costal margins. Rectal examination revealed anterior induration above the prostate.

Investigations.-Haemoglobin 51\% ; white-cell count 4,400/ c.mm. (see Fig. 2). Liver-function tests showed: alkaline phosphatase, 16 K.A. units ; other tests (including bilirubin) normal; E.S.R. $103 \mathrm{~mm}$. in one hour. Blood culture: anaerobic streptococci sensitive to chloramphenicol, tetracycline, and Albamycin T. Chest $x$-ray examination showed opacity at the right base, the appearance being that of either a pleural effusion or a raised diaphragm.

Chest aspiration produced a serous fluid which on culture grew anaerobic streptococci. Deeper aspiration produced thick pus, and to determine the site of this abscess air was injected and an $\boldsymbol{x}$-ray

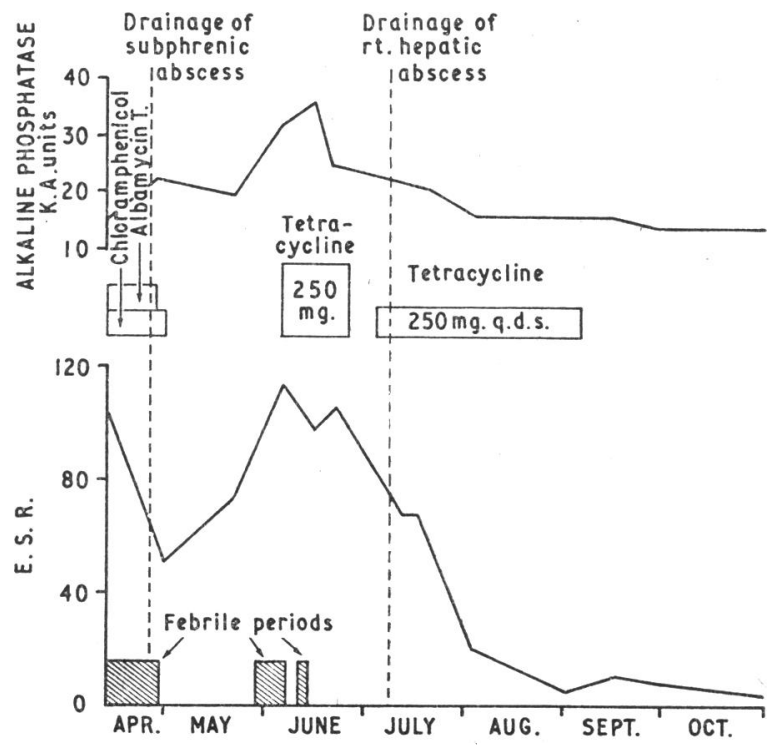
Fig. 2.-Case 7. Changes in E.S.R. and serum alkaline phosphatase that
took place during treatment. 
film taken. This showed the pus to be in the right anterior subphrenic space.

Antibiotic treatment with Albamycin T $250 \mathrm{mg}$. q.d.s. and chloramphenicol $250 \mathrm{mg}$. q.d.s. was started and he was transferred to the London Hospital.

At operation the right anterior subphrenic space was explored through a subcostal incision. A large subphrenic abscess was found containing $800 \mathrm{ml}$. of pus. The liver was explored with an aspiration needle, but no intrahepatic abscess was found. A biopsy specimen of the liver was taken and a large tube drain inserted into the abscess cavity.

His general condition improved and his fever subsided. The abscess cavity drained satisfactorily. He was slightly jaundiced. Two days post-operatively his E.S.R. was $58 \mathrm{~mm}$. in one hour; liver-function tests showed: bilirubin $6.1 \mathrm{mg} . / 100 \mathrm{ml}$; alkaline phosphatase 23 K.A. units; thymol turbidity 1 unit ; zinc sulphate turbidity 2.6 units. Histological report on liver biopsy stated: A strip of fibrous tissue separates a rim of necrotic tissue from the liver parenchyma, which shows atrophy such as would occur owing to interference with the portal blood flow. There are focal collections of polymorphs, associated with destruction of liver cells.

It was noticed that although his temperature was seldom above normal he continued to have a persistent tachycardia. This led to a residual focus of infection being suspected. A sinogram showed that the abscess cavity had contracted down to a narrow track and that there was no evidence of a residual abscess in this space. Four weeks after operation he was afebrile, but his E.S.R, was still 74 $\mathrm{mm}$. in one hour.

Five weeks after operation he became febrile again. He looked ill, but no new physical signs were found. His haemoglobin was $74 \%$; white-cell count 7,800/c.mm. ; E.S.R. $115 \mathrm{~mm}$. in one hour. Liver-function test showed: bilirubin $0.4 \mathrm{mg} . / 100 \mathrm{ml}$.; alkaline phosphatase 33.5 K.A. units; thymol turbidity 2.1 units; zinc sulphate turbidity 10.5 units. A diagnosis of intrahepatic infection was made and tetracycline $250 \mathrm{mg}$. q.d.s. was given. He responded to this treatment in that his fever resolved; but his tachycardia persisted, and after 10 days his E.S.R. was still $95 \mathrm{~mm}$. in one hour and his alkaline phosphatase 36 K.A. units.

It was thought that he might have an intrahepatic abscess which required drainage, so a radioisotope-scanning of the liver area using ${ }^{131}$ I-labelled rose Bengal was carried out. This investigation did not show an abscess cavity.

Antibiotic therapy was continued, but he made no progress. $\mathrm{He}$ felt unwell and slowly lost weight. He began to complain of pain in his right loin. His tachycardia and raised E.S.R. persisted.

Ten weeks after his first operation he was found to have a rounded tender swelling below the right costal margin immediately in front of the mid-axillary line. A fine needle was inserted into this swelling and pus obtained by aspiration.

At operation (two days later) the swelling was explored through a subcostal incision. An abscess cavity about 3 by 2 in. ( 7.5 by $5 \mathrm{~cm}$.) extending upwards and medially was found. Histological examination of the wall of the cavity showed it to have been in the substance of the liver. Antibiotics were instilled into the cavity and the wound was closed round a tube drain.

Only a serous discharge was obtained from the drainage tube and it was removed after a few days as it was thought antibiotics had sterilized the cavity. Pus obtained by aspiration from this abscess contained Gram-positive cocci but was sterile on culture.

Tetracycline therapy was continued and his condition and appetite improved. He felt well and gained weight. He was afebrile and his tachycardia improved.

Two and a half weeks after drainage of the intrahepatic abscess he was discharged from hospital to continue tetracycline therapy and to be followed up as an out-patient. Investigations on discharge showed: haemoglobin $94 \%$; white-cell count $6,500 /$ c.mm. ; E.S.R. $26 \mathrm{~mm}$. in one hour. Liver-function tests showed: bilirubin 0.3 mg./100 ml.; alkaline phosphatase 17.4 K.A. units; thymol turbidity 1.8 units; zinc sulphate turbidity 7.7 units.

Six weeks later he was feeling well and his E.S.R. was down to $15 \mathrm{~mm}$. in one hour and his alkaline phosphatase $16.1 \mathrm{~K}$.A. units. Tetracycline was discontinued. Eight weeks later he had had no recurrence of symptoms; his haemoglobin was $101 \%$, his E.S.R. $5 \mathrm{~mm}$. in one hour, and his alkaline phosphatase $14.1 \mathrm{~K}$.A. units. At the time of his las examination his condition was quite satisfactory and follow-up was being continued.

\section{Discussion}

\section{Incidence and Aetiology}

Pylephlebitis and solitary liver abscess have always been rare conditions. Bryant (1897) reported 11 cases, which represented the total number of cases with this diagnosis admitted to Guy's Hospital in the preceding 20 years.

At the London Hospital during 1930-40, 23 cases of these conditions were seen, representing $0.015 \%$ of all admissions during that time. This incidence is comparable to the incidence reported in a large collected series by Ochsner, DeBakey, and Murray (1938), in which it was $0.0077 \%$ of all hospital admissions.

Figures from the London Hospital for a more recent 10-year period show a marked reduction in the incidence of this condition. The total number seen during the years 1953-63 was seven, and this represented $0.0047 \%$ of all admissions. Incidence in other series varies from $0.0032 \%$ of admissions to Whipps Cross Hospital, Leytonstone (L. de Jode, personal communication, 1964), to $0.49 \%$ in Hongkong (McFadzean, Chang, and Wong, 1953).

Any infective lesion in the portal drainage area may give rise to pylephlebitis or a solitary liver abscess. This lesion may be serious in itself or apparently insignificant. The importance of appendicitis as a cause has declined in recent years. At the London Hospital 12 out of the 23 cases seen during 1930-40 were due to appendicitis, while in 1953-63 no cases due to this cause were seen. The case reported in this paper was seen at St. Margaret's Hospital, Epping.

\section{Diagnosis}

A clinical diagnosis of pylephlebitis or solitary liver abscess can be made by observing a pattern of symptoms, signs, and laboratory findings. For confirmation of the diagnosis, liver biopsy, laparotomy, or post-mortem findings are necessary. The diagnosis of these conditions is often delayed, and this delay may result in a high mortality (Shaldon, 1958).

Most cases present sufficient diagnostic features, and the difficulty is due to the rarity of the condition and consequent unfamiliarity with its features. The Table gives a summary of the main features on which a clinical diagnosis can be made, and the subsequent discussion is based on the material of this Table and the features of the three cases reported in full.

Subphrenic abscess is a condition from which the differential diagnosis may be difficult. Three of the cases were diagnosed as having subphrenic abscess, and only when exploration failed to reveal an abscess was the correct diagnosis made. Subphrenic abscess and intrahepatic suppuration occur concurrently in a small proportion of cases. Harley (1955) examined the records of 188 cases of subphrenic abscess and found concurrent intrahepatic suppuration in $21(11.2 \%)$. One case (No. 7) showed this association.

\section{Clinical Features}

Fever of a moderate or severe remittent type was present in seven out of eight of the cases. The temperature rose to between 103 and $104^{\circ} \mathrm{F}$. ( 39.4 and $40^{\circ} \mathrm{C}$.) in most cases and in some as high as $105^{\circ} \mathrm{F}$. $\left(40.6^{\circ} \mathrm{C}\right.$.). In one case (No. 7) only a low-grade fever was present, and the presenting feature was a persistent tachycardia following successful drainage of a subphrenic abscess. Rigors and sweating attacks occurred in the three cases of pylephlebitis and in all but one of the cases of solitary liver abscess. Colp (1926) and Hawkes (1938) pointed out the importance of rigors in the clinical diagnosis of pylephlebitis, and Hawkes went so far as to say that a clinical diagnosis of pylephlebitis should be made whenever rigors occur 
during an attack of appendicitis. A diagnosis made on this criterion cannot be taken as proved, but if rigors occur while any intra-abdominal infection is being treated the possibility of pylephlebitis being the cause should be considered.

Abdominal pain of a dull continuous character either in the epigastrium or under the right costal margin was present in six of the cases.

An abdominal swelling was palpated at some stage of the illness in five cases. In four cases the swelling was easily recognized as an enlarged liver and two presented palpable swellings which were found at laparotomy to be abscesses arising from the liver.

Faundice was observed in four cases, but was transient and faded while the disease was still active. The fact that the jaundice was transient is important, as a history of jaundice having been present before the patient is admitted and investigated may be the only evidence available that implicates the liver. Profound persistent jaundice is a very common feature of advanced cases.

Loss of weight was a feature of all cases in which measurements were recorded. In cases of many weeks' duration the loss was severe. Weight was regained rapidly when the infection was brought under control.

\section{Laboratory Findings}

The liver-function tests gave abnormal results in five cases. The serum alkaline phosphatase level was the most consistently abnormal finding, but the highest levels were found some time after the onset of the disease. This can be most easily seen by reference to Figs. 1 and 2 , which show graphically the rise and fall of the alkaline phosphatase levels which took place during the course of the disease in two cases. The Table shows that the highest alkaline phosphatase levels were often found some time after admission. The alkaline phosphatase level was raised in those cases in which the bilirubin level was normal as well as in those in which it was raised. The level of alkaline phosphatase in these latter cases continued to rise even though the bilirubin had returned to normal.

The haemoglobin estimation showed a varying degree of anaemia in all cases. Some cases were severely anaemic, as is shown in the Table.

Summary of Clinical and Laboratory Features of Nine Cases of Pylephlebitis or Liver Abscess Admitted to the London Hospital Between 1953 and 1963

\begin{tabular}{|c|c|c|c|c|c|c|c|c|c|c|c|c|c|c|}
\hline \multirow{3}{*}{ Case No. } & \multirow{2}{*}{\multicolumn{2}{|c|}{$\begin{array}{c}\text { Sex } \\
\text { and Age }\end{array}$}} & \multirow{3}{*}{$\begin{array}{c}\begin{array}{c}\text { Type of } \\
\text { Lesion, } \\
\text { Date of } \\
\text { Admission }\end{array} \\
\begin{array}{c}\text { Solitary } \\
\text { liver } \\
\text { abscess } \\
26.6 .54\end{array}\end{array}$} & \multirow{3}{*}{\begin{tabular}{|c|} 
Fever \\
$\begin{array}{c}\text { Moderate } \\
\text { remittent } \\
\text { fever }\end{array}$
\end{tabular}} & \multirow{3}{*}{$\begin{array}{c}\begin{array}{c}\text { Rigors } \\
\text { and } \\
\text { Sweating }\end{array} \\
\begin{array}{c}\text { Sweating } \\
\text { attacks. } \\
\text { No rigors }\end{array}\end{array}$} & \multirow{3}{*}{\begin{tabular}{|l} 
Jaundice \\
$\begin{array}{l}\text { Not } \\
\text { present }\end{array}$
\end{tabular}} & \multirow{3}{*}{$\begin{array}{c}\text { Weight } \\
\text { Loss }\end{array}$} & \multirow{3}{*}{\begin{tabular}{|l}
$\begin{array}{c}\text { Abdominal } \\
\text { Pain }\end{array}$ \\
Present
\end{tabular}} & \multirow{3}{*}{\begin{tabular}{|c|}
$\begin{array}{c}\text { Palpable } \\
\text { Abdominal } \\
\text { Mass }\end{array}$ \\
$\begin{array}{c}\text { Enlarged } \\
\text { liver }\end{array}$
\end{tabular}} & $\begin{array}{c}\text { Highest } \\
\text { Bilirubin } \\
\text { Levels }\end{array}$ & $\begin{array}{c}\text { Highest } \\
\text { Alkaline } \\
\text { Phospha- } \\
\text { tase } \\
\text { Levels }\end{array}$ & $\begin{array}{c}\text { Highest } \\
\text { E.S.R. }\end{array}$ & \multirow{3}{*}{\begin{tabular}{|c|} 
Haemo- \\
globin and \\
W.B.C. on \\
Admission \\
\\
$67 \%$. \\
$13,000 /$ \\
c.mm. \\
$77 \%$ \\
poly- \\
morphs
\end{tabular}} & \multirow{3}{*}{$\begin{array}{l}\begin{array}{c}\text { Positive } \\
\begin{array}{c}X-\text { ray } \\
\text { Evidence }\end{array}\end{array} \\
\begin{array}{l}\text { Right } \\
\text { dia- } \\
\text { phragm } \\
\text { raised }\end{array}\end{array}$} \\
\hline & & & & & & & & & & \multicolumn{3}{|c|}{ Date of Estimation } & & \\
\hline & $\mathbf{M}$ & 33 & & & & & & & & $\begin{array}{c}0.4 \mathrm{mg} . / \\
100 \mathrm{ml} . \\
6.7 .54\end{array}$ & $\begin{array}{l}\text { 9.2 K.A. } \\
\text { units } \\
6.7 .54\end{array}$ & $\begin{array}{l}122 \mathrm{~mm} \text {. } \\
\text { in } 1 \mathrm{hr} \text {. } \\
28.6 .54\end{array}$ & & \\
\hline 2 & $\mathbf{F}$ & 59 & $\begin{array}{l}\text { Solitary } \\
\text { liver } \\
\text { abscess } \\
10.5 .53\end{array}$ & $\begin{array}{c}\text { Severe } \\
\text { remittent } \\
\text { fever }\end{array}$ & $\begin{array}{l}\text { Rigors } \\
\text { and } \\
\text { sweating } \\
\text { attacks }\end{array}$ & $\begin{array}{l}\text { Not } \\
\text { present }\end{array}$ & $\overline{\text { Moderate }}$ & Present & $\begin{array}{c}\text { Enlarged } \\
\text { liver }\end{array}$ & $\begin{array}{l}1 \mathrm{mg} . / \\
100 \mathrm{ml} . \\
11.5 .55\end{array}$ & $\begin{array}{c}\text { Not } \\
\text { estimated }\end{array}$ & $\begin{array}{l}100 \mathrm{~mm} . \\
\text { in } 1 \mathrm{hr} . \\
15.4 .55\end{array}$ & $\begin{array}{l}66 \% . \\
9,700 \\
\text { c.mm. } \\
79 \% \\
\text { poly- } \\
\text { morphs }\end{array}$ & $\begin{array}{l}\text { Right } \\
\text { dia- } \\
\text { phragm } \\
\text { high; } \\
\text { moved } \\
\text { freely }\end{array}$ \\
\hline 3 & $\mathbf{M}$ & 53 & $\begin{array}{c}\text { Pylephle- } \\
\text { bitis } \\
15.9 .58\end{array}$ & $\begin{array}{c}\text { Severe } \\
\text { remittent } \\
\text { fever }\end{array}$ & \begin{tabular}{|l|} 
Rigors \\
and \\
sweating \\
attacks
\end{tabular} & $\begin{array}{l}\text { Present } \\
\text { on ad- } \\
\text { mission }\end{array}$ & $\begin{array}{l}\text { Not } \\
\text { recorded. } \\
\text { Acute } \\
\text { illness }\end{array}$ & $\begin{array}{l}\text { Not } \\
\text { present }\end{array}$ & $\begin{array}{l}\text { Not } \\
\text { present }\end{array}$ & $\begin{array}{c}5 \mathrm{mg} . / \\
100 \mathrm{ml} . \\
16.9 .58 \\
\text { Alk. Phos. } \\
15 \text { units }\end{array}$ & $\begin{array}{c}44 \mathrm{~K} . \mathrm{A} . \\
\text { units } \\
29.9 .58 \\
\text { Bilirubin } \\
1.2 \mathrm{mg} . / \\
100 \mathrm{ml} .\end{array}$ & $\begin{array}{l}50 \mathrm{~mm} \text {. } \\
\text { in } 1 \mathrm{hr} \text {. } \\
15.9 .58 . \\
\text { No other } \\
\text { estima- } \\
\text { tion }\end{array}$ & $\begin{array}{l}85 \% \\
11,000 / \\
\text { c.mm. } \\
76 \% \\
\text { poly- } \\
\text { morphs }\end{array}$ & \\
\hline 4 & $\mathbf{M}$ & 2 days & \begin{tabular}{|c|} 
Multiple \\
abscesses \\
$\mathbf{1 8 . 2 . 5 8}$
\end{tabular} & . & Premature in & fant. & o clinical d & etails availab & & & & & & \\
\hline 5 & $\mathbf{M}$ & 59 & $\begin{array}{l}\text { Solitary } \\
\text { liver } \\
\text { abscess } \\
22.7 .59\end{array}$ & $\underset{\text { pyrexia }}{\text { Remittent }}$ & $\begin{array}{l}\text { Rigors } \\
\text { and } \\
\text { sweating } \\
\text { attacks }\end{array}$ & $\begin{array}{l}\text { Not } \\
\text { present }\end{array}$ & $\begin{array}{l}\text { Rapid in } \\
4 \text { weeks } \\
\text { before } \\
\text { admis- } \\
\text { sion }\end{array}$ & $\begin{array}{l}\text { Not } \\
\text { present }\end{array}$ & $\begin{array}{l}\text { Not } \\
\text { present }\end{array}$ & $\begin{array}{c}0.1 \mathrm{mg} . / \\
100 \mathrm{ml} . \\
29.7 .59 \\
\text { (after } \\
\text { drainage) }\end{array}$ & $\begin{array}{c}10 \cdot 0 \mathrm{~K} . \mathrm{A} . \\
\text { units } \\
29.7 .59 \\
\text { (after } \\
\text { drainage) }\end{array}$ & $\begin{array}{l}90 \mathrm{~mm} . \\
\text { in } 1 \mathrm{hr} . \\
18.6 .59\end{array}$ & $\begin{array}{l}72 \% \\
23,700 \\
\text { c.mm. } \\
77 \% \\
\text { poly- } \\
\text { morphs }\end{array}$ & $\begin{array}{l}\text { Right } \\
\text { dia- } \\
\text { phragm } \\
\text { raised. } \\
\text { Small } \\
\text { right } \\
\text { pleural } \\
\text { effusion }\end{array}$ \\
\hline 6 & $\mathbf{M}$ & 25 & $\begin{array}{l}\begin{array}{l}\text { Solitary } \\
\text { liver }\end{array} \\
\text { abscess } \\
3.3 .61\end{array}$ & $\begin{array}{c}\text { Moderate } \\
\text { remittent } \\
\text { pyrexia }\end{array}$ & $\begin{array}{l}\text { Not } \\
\text { present }\end{array}$ & Present & $\begin{array}{l}\text { Not } \\
\text { recorded }\end{array}$ & Present & $\begin{array}{c}\text { Enlarged } \\
\text { liver }\end{array}$ & $\begin{array}{c}1.4 \mathrm{mg} \cdot / \\
100 \mathrm{ml} . \\
9.3 .61\end{array}$ & $\begin{array}{c}21 \text { K.A. } \\
\text { units } \\
9: 3.61\end{array}$ & $\begin{array}{l}103 \mathrm{~mm} . \\
\text { in } 1 \mathrm{hr} \text {. } \\
8.3 .61\end{array}$ & $\begin{array}{l}89 \% . \\
10,700 \\
\text { c.mm. } \\
65 \% \\
\text { poly } \\
\text { morphs }\end{array}$ & \\
\hline 7 & $\mathbf{M}$ & 41 & $\begin{array}{c}\text { Solitary } \\
\text { abscess } \\
25.4 .63\end{array}$ & $\begin{array}{l}\text { Low- } \\
\text { grade } \\
\text { fever }\end{array}$ & $\begin{array}{l}\text { One } \\
\text { rigor } \\
\text { only }\end{array}$ & $\begin{array}{l}\text { Present } \\
\text { on } \\
\text { admis- } \\
\text { sion }\end{array}$ & Moderate & Present & $\begin{array}{l}\text { Swelling } \\
\text { in right } \\
\text { loin }\end{array}$ & $\begin{array}{c}6.1 \mathrm{mg} . / \\
100 \mathrm{ml} . \\
27.4 .63 \\
\text { Alk. Phos. } \\
23 \mathrm{~K} . \mathrm{A} . \\
\text { units }\end{array}$ & $\begin{array}{c}36 \text { K.A. } \\
\text { units } \\
17.6 .63 \\
\text { Bilirubin } \\
0.2 \mathrm{mg} .\end{array}$ & $\begin{array}{l}115 \mathrm{~mm} \text {. } \\
\text { in } 1 \mathrm{hr} \text {. } \\
5.6 .63\end{array}$ & $\begin{array}{c}51 \% . \\
4,400 \\
\text { c.mm. }\end{array}$ & $\begin{array}{l}\text { Right } \\
\text { pleural } \\
\text { effusion } \\
\text { and } \\
\text { sub- } \\
\text { phrenic } \\
\text { abscess }\end{array}$ \\
\hline $8^{*}$ & $\mathbf{M}$ & 9 & \begin{tabular}{|l|} 
Pylephle- \\
bitis \\
19.4 .61
\end{tabular} & $\begin{array}{l}\text { Severe } \\
\text { remittent } \\
\text { pyrexia }\end{array}$ & $\begin{array}{l}\text { Rigors } \\
\text { and } \\
\text { sweating } \\
\text { attacks }\end{array}$ & Present & $\begin{array}{l}\text { Very } \\
\text { severe }\end{array}$ & Present & $\begin{array}{c}\text { Enlarged } \\
\text { liver }\end{array}$ & $\begin{array}{c}2.5 \mathrm{mg} .1 \\
100 \mathrm{ml} . \\
21.6 .61 \\
\text { Alk. phos. } \\
8.2 \mathrm{~K} . \mathrm{A} \text {. } \\
\text { units }\end{array}$ & $\begin{array}{c}\text { 19.2 K.A. } \\
\text { units } \\
25.7 .61 \\
\text { Bilirubin } \\
0.5 \mathrm{mg} .\end{array}$ & $\begin{array}{l}43 \mathrm{~mm} \text {. } \\
\text { in } 1 \mathrm{hr} \text {. } \\
25.7 .61\end{array}$ & $\begin{array}{l}49 \% . \dagger \\
17,000 \\
\text { c.mm. } \\
84 \% \\
\text { poly- } \\
\text { morphs }\end{array}$ & $\begin{array}{l}\text { Raised } \\
\text { dia- } \\
\text { phragm. } \\
\text { Small } \\
\text { pleural } \\
\text { effusion }\end{array}$ \\
\hline 9* & $\mathbf{M}$ & 45 & $\begin{array}{l}\text { Pylephle- } \\
\text { bitis } \\
29.8 .62\end{array}$ & $\begin{array}{l}\text { Severe } \\
\text { remittent } \\
\text { pyrexia }\end{array}$ & $\begin{array}{l}\text { Rigors } \\
\text { and } \\
\text { sweating } \\
\text { attacks }\end{array}$ & $\begin{array}{l}\text { Not } \\
\text { present }\end{array}$ & Severe & Present & $\begin{array}{l}\text { Enlarged } \\
\text { liver }\end{array}$ & $\begin{array}{c}0.4 \mathrm{mg} . / \\
100 \mathrm{ml} . \\
15.11 .62\end{array}$ & $\begin{array}{c}37 \cdot 0 \mathrm{~K} . \mathrm{A} . \\
\text { units } \\
15.11 .62\end{array}$ & $\begin{array}{l}115 \mathrm{~mm} . \\
\text { in } 1 \mathrm{hr} \text {. } \\
15.10 .62\end{array}$ & $\begin{array}{l}77 \% . \dagger \\
15,000 \\
\text { c.mm. }\end{array}$ & $\begin{array}{l}\text { Impair- } \\
\text { ment of } \\
\text { move- } \\
\text { ment of } \\
\text { right } \\
\text { dia- } \\
\text { phragm }\end{array}$ \\
\hline
\end{tabular}


The white-cell count gave variable results. Most cases had a high polymorphonuclear count, but in some it was within normal limits. Apart from confirming the presence of pyogenic infection, the polymorphonuclear count is not of value in establishing the diagnosis.

The sedimentation rate was raised in all cases, and in five it was $100 \mathrm{~mm}$. or over in one hour. The sedimentation rate has no specific diagnostic value, but these high rates would seem to form a feature in the pattern of the disease.

\section{Radiology}

$X$-ray examination assisted in the establishment of the diagnosis in six cases. The abnormalities noted were a raised right diaphragm in four cases and a small pleural effusion in three. In one case the only abnormality was a slight impairment of movement of the right diaphragm on screening. Pancoast (1926) described the radiological appearances of these cases in detail.

\section{Histopathology}

To confirm a diagnosis of pylephlebitis before abscess formation has taken place histological evidence is desirable. This evidence was obtained in the cases reported.

The diagnostic histological feature is the presence of pus or infected thrombus in a branch of the portal vein. Inflammatory infiltration of the portal tracts is not diagnostic of pylephlebitis, since it may occur as a reaction of the reticuloendothelial system to infection in any part of the body.

\section{Treatment}

The results of treatment of these conditions since the introduction of antibiotics have greatly improved. During the 10-year period 1930-40 two cases, one of pylephlebitis and one of solitary liver abscess, recovered out of 23 treated at the London Hospital. The solitary liver abscess was drained, and the case of pylephlebitis received a single injection of mercurochrome into the portal system. The latter procedure was also carried out in two other cases without beneficial effect.

This high mortality can be compared with the 10-year period 1953-63 during which six out of seven patients with these conditions at the London Hospital recovered. There have been a number of reports of successful treatment (Ottenberg and Berck, 1938 ; Wilensky, 1945 ; Gamm, 1945 ; D’Abreu, 1946 ; Wishart and Peterson, 1947 ; Shaldon, 1958 ; Klinefelter, Grose, and Crawford, 1960).

Shaldon (1958) expressed doubts regarding the value of antibiotic treatment alone in these cases. In a series of 10 cases he found that recovery occurred only in cases treated by operation in addition to antibiotics. He thought that reports of recovery occurring without a laparotomy being undertaken were open to question, as the diagnosis could not be confirmed.

The difficulty in establishing a firm diagnosis has also resulted in it not being known how often pylephlebitis occurs and resolves with or without antibiotic treatment. Some cases of unexplained fever following treatment of abdominal infection may be due to pylephlebitis which resolves.

\section{Antibiotic Therapy}

Antibiotics were used in all cases in the present series. Pus for culture cannot be obtained in all cases, and a trial of various antibiotics is then necessary. The infecting organism is most commonly of a type derived from the bowel. The infecting organisms in the recent series were $E$. coli in two cases and nonhaemolytic streptococcus in three. Full doses of broad-spectrum antibiotics should be given, and when a satisfactory response is obtained treatment should be continued until there is evidence that the infection has been completely eliminated. The usual criteria for the elimination of infection are a clinical recovery and the absence of fever. Relapse occurred in three cases when antibiotic therapy was discontinued, using these criteria that the infection had been eliminated, and one of these cases relapsed three times. These relapses show that these clinical criteria are insufficient and that before treatment is discontinued further evidence of complete quiescence of the infection should be obtained. The sedimentation rate and the liver-function tests may provide the necessary evidence.

The value of these two investigations in assessing the progress of a case is shown by Figs. 1 and 2. Fig. 1 shows the changes in the sedimentation rate and alkaline phosphatase levels which occurred during the treatment of a case of pylephlebitis. This case (No. 9) had a recurrence of symptoms on two occasions when antibiotics were discontinued while the E.S.R. and alkaline phosphatase levels were raised. Fig. 2 shows the same changes in another case (No. 7). This patient remained unwell and had a raised E.S.R. and serum alkaline phosphatase following drainage of a subphrenic abscess. This was thought to be due to either an intrahepatic abscess or pylephlebitis, and antibiotic treatment was started. The response in this case was not as good as was expected and the presence of a hidden abscess was strongly suspected. A swelling below the right costal margin was found to be an abscess and was drained. After drainage of this abscess the sedimentation rate and liverfunction tests showed that a more rapid improvement was occurring. Antibiotics were continued for many weeks until the tests were almost normal, and no recurrence has so far taken place. The necessity of a long course of antibiotics is stressed by Cronin (1961). The cases reported by D'Abreu (1946) and Klinefelter et al. (1960) relapsed after antibiotics had been discontinued on clinical evidence of elimination of infection.

\section{Steroid Treatment}

Prednisone given in addition to antibiotics was used for the treatment of two cases from St. Margaret's Hospital, Epping (see Table). The first of these was a desperately ill child with pylephlebitis and multiple small hepatic abscesses. Prednisone $10 \mathrm{mg}$. six-hourly was given in conjunction with tetracycline $250 \mathrm{mg}$. q.d.s., and Altafur (furaltadone) $125 \mathrm{mg}$. q.d.s. A rapid improvement in his condition followed within 24 hours and eventually complete recovery took place.

The beneficial effect in this case led to the use of prednisone in a second case which had relapsed three times. The patient progressed well and seemed to make a complete recovery. It is impossible to assess the value of prednisone in this case because he might have responded equally well to prolonged antibiotic therapy alone. Stokes (1960) used steroid therapy in the treatment of a solitary liver abscess in order to inhibit fibroustissue formation and allow the antibiotics to penetrate into the abscess cavity.

\section{Treatment of Abscesses}

Intrahepatic abscesses may be treated by drainage or by closed aspiration. Drainage was carried out in four cases in this series. Two were diagnosed at laparotomy and were treated by inserting tube drains into the abscess cavity. Drainage in these cases was transperitoneal, but the result was satisfactory.

One case was explored through a loin incision as the patient had a swelling in this region, and satisfactory extraperitoneal drainage with a tube drain was obtained.

Another case was treated by closed aspiration, and the result was quite satisfactory. A method of closed aspiration and replacement by air and antibiotics has been described by 
McFadzean et al. (1953), who successfully treated 14 cases by this method.

\section{Summary}

Pylephlebitis and solitary liver abscess are both sequels to intra-abdominal infection.

The incidence of pylephlebitis after appendicitis was much less in the past 10 years than in the years 1930-40. The incidence of pylephlebitis and solitary liver abscess due to other causes is not reduced to the same extent.

The outlook is very much better for cases treated in the past 10 years than for cases treated in 1930-40.

A clinical diagnosis can be made by recognizing a pattern of clinical features and laboratory findings.

Laparotomy findings or histopathological evidence is required for confirmation of the diagnosis.

Treatment is by elimination of any known intra-abdominal infection, administration of an adequate course of antibiotics, and drainage of intrahepatic abscesses if present.

There is a tendency for rclapse to occur when treatment is discontinued, and laboratory tests are of assistance in judging the progress of the case and in deciding when antibiotics should be discontinued.
I would like to thank the surgeons of the London Hospital and St. Margaret's Hospital, Epping, for permission to publish details of cases admitted under their care; Mr. E. C. B. Butler for his encouragement and help in the preparation of this paper; and Professor Doniach and Dr. K. Weinbren, of the Bernhard Baron Institute of Pathology, for their help in the interpretation of the histology of these cases.

\section{RBFERENCES}

Beaver, D. C. (1931). Amer. 9. Path., 7, 259.

Bryant, J. H. (1897). Guy's Hosp. Rep., $54,77$.

Colp, R. (1926). Surg. Gynec. Obstet., 43, 627.

Cronin, K. (1961). Gut, 2, 53.

D'Abreu, F. (1946). Proc. roy. Soc. Med., 39, 309

Eliason, E. L. (1926). Surg. Gynec. Obstet., $42,510$.

Gamm, K. E. (1945). \%. Amer. med. Ass., 128, 1159.

Harley, H. R. S. (1955). Ann. roy. Coll. Surg. Engl., 17, 201.

Hawkes, S. Z. (1938). Surg. Gynec. Obstet., 66, 62.

Klinefelter, H. F., Grose, W. E., and Crawford, H. J. (1960). Bull. fohns Hopk. Hosp., 106, 65.

McFadzean, A. J. S., Chang, K. P. S., and Wong, C. C. (1953). Brit. \$. Surg., 41, 141.

Ochsner, A., DeBakey, M., and Murray, S. (1938). Amer. f. Surg., 40, 292.

Ottenberg, R., and Berck, M. (1938). F. Amer. med. Ass., 111, 1374.

Pancoast, H. K. (1926). Amer. F. Roentgenol., 16, 303.

Rothenberg, R. E., and Linder, W. (1934). Surg. Gynec. Obstet., 59, 31. Shaldon, C. (1958). Brit. 7. Surg., 45, 357.

Stokes, J. F. (1960). Lancet, 1, 355.

Wtilensky, A. O. (1945). N.Y. St. Э. Med., 45, 2082

Wishart, J. H., and Peterson, L. J. (1947). F. Amer. med. Ass., 133, 539.

\title{
Use of 6-Phosphogluconate Dehydrogenase as a Screen Test for Cervical Carcinoma in Normal Women
}

\author{
G. G. MUIR,* M.B., в.S., M.SC. ; G. CANTI, † M.B., B.S., M.C.PATH ; D. WILLIAMS, $\ddagger$ M.B., B.S., F.R.C.S., M.R.C.o.G.
}

The remarkable achievements of exfoliative cytology in the early diagnosis of occult carcinoma of the cervix have shown that it is desirable to screen all women over 30 . Unfortunately, such a large survey would overwhelm our cytological services, which are limited by the shortage of cytologists and technicians. For this reason attempts have been made to employ some of the basic biochemical properties of the malignant cell in diagnostic tests.

Odell and Burt (1950) and Fishman et al. (1950) reported their experiences in the use of beta-glucuronidase as a diagnostic test for carcinoma of the cervix. In both series it was found that with carcinoma there was likely to be a higher level of betaglucuronidase in the vaginal fluid than in normal women. In post-menopausal women the distinction was not so clear. Lawson (1959) obtained similar results in this country but found not only an overlap of enzyme values in benign and malignant conditions but also low levels in certain cases of carcinoma of the cervix. Hatzimichael (1962) studied the content of beta-glucuronidase in the cervical mucous plug, as distinct from vaginal fluid, and found in general a marked difference between benign and malignant conditions. $\mathrm{He}$ also found that carcinoma of the cervix was very seldom associated with low levels of beta-glucuronidase in cervical mucus.

Beta-glucuronidase, from the length of estimation and its biochemical properties, has certain disadvantages as a screening test (Walker, 1952 ; Walker and Levvy, 1952, 1953 ; de Duve et al., 1955 ; Watkins and Lawson, 1963).

- Assistant Chemical Pathologist, St. Bartholomew's Hospital, London. † Cytologist. St. Bartholomew's Hospital, London.

¥ Resident Assistant Obstetric and Gynaecological Surgeon, St. Bartholomew's Hospital, London.
Bonham and Gibbs (1962) estimated the 6-phosphogluconate dehydrogenase content of the high vaginal fluid in a number of selected benign and malignant gynaecological conditions. In their series the enzyme levels gave a definite distinction between benign and malignant disease, there being only three benign conditions with high levels of enzyme and no cases of carcinoma with low levels.

Both histochemically and biochemically 6-phosphogluconate dehydrogenase has been shown to be increased in benign and malignant hyperplasias (Chayen, 1961 ; Kotnis et al., 1962a, 1962b ; Scott et al., 1962). 6-Phosphogluconate dehydrogenase is a cytoplasmic enzyme which facilitates its release from the cellular debris of the vaginal fluid. As the enzyme is linked to nicotine adenine dinucleotide phosphate, changes in ultraviolet absorption give a simple and rapid means of estimation.

A "well women's diagnostic clinic" has been established in the gynaecological department of this hospital in conjunction with the Corporation of the City of London. Here women are screened for carcinoma of the cervix by means of pelvic examination and exfoliative vaginal and cervical cytology. Such a clinic provides ideal material for the evaluation of the enzyme assay as a screening test, and this paper reports our preliminary findings.

\section{Methods}

The samples were obtained in a manner similar to that described by Bonham and Gibbs (1962). The enzyme assay was essentially that of Glock and McLean (1953) modified by Bonham and Gibbs (1962). Following these authors an enzyme 